\title{
関東圈在住幼児の体力・運動能力と就学前の保育・教育施設内および施設外における
} 運動・スポーツの実施状況や日常の身体活動量に関する横断的研究

\author{
田中 千晶 ${ }^{1}$, 引原 有輝 ${ }^{2}$, 安藤 貴史 ${ }^{3}$, 大河原 一憲 ${ }^{4}$,
} 薄井 澄誉子 ${ }^{3}$, 佐々木 玲子 $^{5}$, 田中 茂穂 ${ }^{3}$

\section{Relationship of exercise at preschool and out of school and daily physical activity to physical fitness in preschool children in the Kanto region: a cross-sectional study}

\author{
Chiaki Tanaka ${ }^{1}$, Yuki Hikihara ${ }^{2}$, Takafumi Ando ${ }^{3}$, Kazunori Ohkawara ${ }^{4}$, \\ Chiyoko Usui ${ }^{3}$, Reiko Sasaki ${ }^{5}$ and Shigeho Tanaka ${ }^{3}$
}

${ }^{1}$ 桜美林大学総合科学系， ₹194-0294 東京都町田市常盤町 3758 (J. F. Oberlin University, 3758 Tokiwamachi, Machida, Tokyo 194-0294, Japan)

2 千葉工業大学，＝275-0023 千葉県習志野市芝園 2-1-1 (Department of Education Center (Sports Science), Faculty of Engineering, Chiba Institute of Technology, 2-1-1 Shibazono, Narashino, Chiba 275-0023, Japan)

3 独立行政法人国立健康・栄養研究所基礎栄養研究部， １62-8636 東京都新宿区戸山 1-23-1 (Department of Nutritional Science, National Institute of Health and Nutrition, 1-23-1 Toyama, Shinjuku-ku, Tokyo 162-8636, Japan)

${ }^{4}$ 国立大学法人電気通信大学， = 182-8585 東京都調布市調布ヶ丘 1-5-1 (The University of Electro-Communications, 1-5-1 Chofugaoka, Chofu, Tokyo 182-8585, Japan)

5 慶応義塾大学体育研究所， ７223-8521 神奈川県横浜市港北区日吉 4-1-1 (Institute of Physical Education, Keio University, 4-1-1 Hiyoshi, Kohoku-Ku, Yokohama, Kanagawa 223-8521, Japan)

Received: December 7, 2013 / Accepted: April 3, 2014

\begin{abstract}
This study sought to examine the potential relationships of physical education (PE) participation at preschool and sports club (SC) participation out of school and daily physical activity (PA) measured objectively using a triaxial accelerometer, with physical fitness in preschool children. Physical fitness testing was used to measure both health-related and skill-related parameters of fitness in 191 Japanese preschoolers in the Kanto region (94 boys and 97 girls, $5.6 \pm 0.6$ years). Daily PA was assessed using a triaxial accelerometer (ActivTracer, GMS) for 6 consecutive days, including weekdays and weekend days. PE and SC participation was assessed using questionnaires for preschool teachers or parents of subjects, respectively. All health-related and skill-related physical fitness and total Z-score were correlated with time spent with physical activity ratio (PAR) $\geqq 4$ when adjusted for age, sex, body height and weight. In addition, greater grip strength was associated with PE participation at preschool, and $25 \mathrm{~m}$ run speed was associated with SC participation, also. However, $25 \mathrm{~m}$ run speed was negatively associated with PE participation. These findings suggest that daily PA may contribute to the development of both health-related and skill-related fitness in preschool children, although further research on the cause-effect relationship is needed. Moreover, participation in a SC may contribute to the development of running speed.
\end{abstract}

Jpn J Phys Fitness Sports Med, 63(3): 323-331 (2014)

Keywords : physical fitness, sports participation, physical activity, accelerometer, young children

\section{はじめに}

近年の研究報告において, 最近の幼児の体力・運動能 力は，1980年代の幼児と比較すると劣っていることが指 摘されている1). 同様に，学童期以降の全国の子供を対 象とした文部科学省 ${ }^{2}$ の調査結果においても体力・運動 能力の低下がみられ，幼児期の低い体力・運動能力が学
童期まで影響している可能性が考えられる。そこで文部 科学省は，2012年に幼児期運動指針 ${ }^{3)}$ 策定し，幼児期 から身体を動かす習慣をつける必要性を指摘している。

日本では，女性の社会進出により保育所への入所を希 望する待機児童が増加している半面，幼稚園の園児数は 減少し続けている ${ }^{4)}$. 幼稚園の中には入園希望者を増や すために，保護者に対して魅力ある教育内容のひとつと 
して，専門家による運動指導を導入している園もある。 保育所でも, 保育所保育指針の改定 ${ }^{5)}$ により, 養護と教 育の一体的な実施という保育所の特性が明確化され，保 育所内に扔いても運動指導事業が拡大している.他にも, 運動・スポーツを通じて子どもの健全な発育発達を促す ことや子どもの可能性を広げることを目的に, 古くから 民間のスポーツクラブ, 地域のスポーツ施設や, 最近で は総合型地域スポーツクラブなどにおいて, 幼児を対象 とした水泳，体操，サッカー，テニス，ダンスなど多岐 に亘る種目の教室が開催されている ${ }^{6)}$.

学童期以降は, 文部科学省の体力 ・ 運動能力調查 ${ }^{7)}$ に 捛いても報告されているように, 学校内での体育以外に 運動・スポーツに参加している子どもに扔いて体力・運 動能力が高いことは, 当然の事実としてとらえられてき た. しかし, 報告数は限られているものの, 日本に扔け る幼児の体力・運動能力と運動指導との関係について, 運動指導が多い幼稚園の園児は, むしろ体力・運動能力 が低いという結果が報告されている ${ }^{8)}$. 一方で, 体力・ 運動能力と地域や民間のスポーツクラブなどでの運動・ スポーツ (以下, SC: sports club out of school) への参加 状況との関係については, 我々の知る限り報告は見られ ない.

また,これら運動・スポーツの実施状況と体力・運動 能力の関連を検討する上で, 運動・スポーツの実施を含 めた日常生活全般における身体活動量の把握が重要と考 えられる. 国内外の幼児に扔いて, 日常生活全般の身体活 動量を客観的に評価し, 体力・運動能力や体格といった 健康関連指標との関倸について検討した報告では, 両者 の間に有意な関係が見られることが報告されている9-14). 一方で，学童期に扔ける研究結果であるが，小学校間で 体育指導による身体活動量に大きな差がみられても, 体 育以外の時間に扔ける日常生活全般の身体活動量を含め ると，学校間の差が消失したという国外の報告もある ${ }^{15)}$. したがって, 幼児期の体力・運動能力に及ぼす運動・又 ポーツの実施状況や日常生活全般の身体活動量の複合的 な検討が必要である.

そこで, 本研究では, 幼児の体力・運動能力に対し, 現在通っている就学前の保育・教育施設での運動指導 (以 下, PE: physical education at preschool) の受講や SCへ の参加の有無，および加速度計 ${ }^{16,17)}$ を用いて評価した日 常生活全般における身体活動量（強度・時間）が, それ ぞれどの程度の関倸性があるのかを検討し，幼児期にお ける運動・スポーツ指導や運動・スポーツに限らない日 常生活に打ける身体活動の意義を明らかにすることを目 的とした。

\section{方 法}

対象者 対象は, 本研究の実施に保護者が同意した東京
都, 神奈川県, 埼玉県, 茨城県の就学前の保育・教育施 設に通っている, 年中または年長クラスの191名（男子 94名打よび女子97名)であった，保護者への問診により， 甲状腺機能の異常などエネルギー代謝や通常の身体活動 に影響を与えると考えられる疾病についての既往歴が無 いことを確認した。本研究は桜美林大学の倫理委員会の 許可を得て実施した。測定にあたって，保護者に測定の 目的, 利益, 不利益, 危険性, デー夕の公表について説 明を行い，書面にて同意を得た。

測定項目 PEの実施頻度および内容に関しては，各施 設の施設長に対し, 対象者が所属するクラスの状況につ いて，質問紙を用いて尋ねた。一方，SCへの参加頻度扔 よび種目名については，質問紙を用いて対象者の保護者 に尋ねた。

身体活動量の調查は，原則として木曜の登園後，用意 したベルトに， 3 軸加速度計であるアクティブトレー サー（AC210, GMS社製，日本，72.5×41.5×27.5 mm, 60 g）を装着し，一週間後の同じ曜日の登園後に回収した。 水泳や着替え，風呂などやむを得ない場合を除いて装着 するように依頼した。装着しなかった時間および睡眠時 間については, 記録をつけてもらった，加速度計の值は, 全ての測定が終了した後、コンピュータに取り込み，保 護者による記録とあわせて, 加速度計の值から判断して 睡眠時や着替え以外に 1 日合計 2 時間以上装置を装着し ていないと考えられる場合は，その日のデー夕は採用し ないこととした．アアクティブトレーサーで得られた 3 軸 方向それぞれの平均加速度を 1 分毎に算出した．幼児の 身体活動量の評価に打けるアクティブトレーサーを用い た推定式は, 先行研究に扔いて報告されている ${ }^{16)}$ そその 報告に基づき，ボール投げのように連続的な歩・走行を 伴わない活動については, 垂直/水平の加速度比から判 別して補正する方法を採用した。この方法を用いること により, 階段昇降以外の活動については, 平均として正 確に身体活動強度を推定できる。なお，本研究で用いた 3 軸加速度計は, 業者による振動テストにより機械的な 信頼性が保証されている。

MET (metabolic equivalent) 值は, 成人の場合 1 $\mathrm{MET}=3.5 \mathrm{~mL} / \mathrm{kg} / \mathrm{min}$ と仮定して求めることが多い.し かし, 子どもでは $1 \mathrm{MET}$ が $3.5 \mathrm{~mL} / \mathrm{kg} / \mathrm{min}$ より大きくな るため, 身体活動強度を基礎代謝量の倍数として表した PAR (physical activity ratio) を用いることも多い18.19). そこで，合成加速度の值を用いたPARの推定式 ${ }^{16)} に よ$ り，1 分間毎のPARを推定した．記録により睡眠とされ た時間についてはPARを1.03, 着替えについては2.4 (着 替え, シャワーのMETs 2.0 より), 入浴時間は, 10分ま でを2.4（着替え, シャワーのMETs 2.0 より）を，それ以 上は1.8 (bath sittingの METs 1.5 より) を当てはめた20). 
こうして得られたPARから，身体活動レベル（physical activity level: PAL) を推定した。これは，24時間当たり の平均のPARに相当する。

身長と体重は, 各々, $0.1 \mathrm{~cm}$ と $0.1 \mathrm{~kg}$ 単位で計測した。 健康関連体力については, 筋力の指標として握力, 全身 持久力の指標として $20 \mathrm{~m}$ シャトルランの 2 項目を測定 した，握力は，左右の手で 2 回ずつ測定し，それぞれの 大きい方の值の平均值を用いた， $20 \mathrm{~m}$ シャトルランは, 1 回のみ実施した。スキル関連体力については，パワー の指標として立ち幅跳び, 調整力の指標としてとび越し くぐり，スピードの指標として $25 \mathrm{~m}$ 走の計 3 項目を測 定し，何れの測定も 2 回測定したうちの優れた方の值を 用いた，とび越しくぐり以外の測定項目については, 新. 日本人の体力標準值 $I^{21)}$ に準じて実施した。また，とび 越しくぐりについては, 体育科学センター ${ }^{22)}$ に準じて 実施した。

統計処理 PARがそれぞれ 2 以上〜 3 未満， 3 以上〜 4 未満および 4 以上の所要時間については, 平日の平均 值と土日・祝日の平均值を求め, それぞれ 5 日，2 日と 重み付けすることによって, 個人毎の代表值を求めた。 なお，土曜日を保育所で生活していた保育所児について は，平日の值として算出に用いた。多くの幼児において は，平日 4 日，土日・祝日それぞれ 1 日ずつの測定值が 得られたが，少なくとも平日 2 日以上，土日・祝日のい ずれか 1 日以上のデータが得られた者を, 分析に用いた。

データの正規性の検定を行ったところ, $20 \mathrm{~m}$ シャト ルラン, とび越しくぐり, $25 \mathrm{~m}$ 走, PARが 2 以上 3 未 満掞よびPARが 4 以上の所要時間の正規性は認められ なかった，そこで, $20 \mathrm{~m}$ シャトルラン, とび越しくぐり, PARが 2 以上〜 3 未満抒よびPARが 4 以上の所要時間 については, 自然対数変換を行い, その後の分析に用い た。なお， $25 \mathrm{~m}$ 走については，正規性の検定を行うと, $\mathrm{p}=0.043$ であったが, 対数や平方根をとっても有意であっ たことから，対数変換は行わずに検定に用いた，また， 体力・運動能力を総合的に評価するため, 各項目につい て Z得点を算出し，さらに，それらを積算した值を分析 に用いた。

性差の検討は対応のない $\mathrm{t}$ 検定を行った，PEの受講 およびSCへの参加の有無による体力・運動能力の比較 については, 体力・運動能力を目的变数, PEの受講抒 よびSCへの参加の有無および日常の身体活動量を説明 変数とした共分散分析 (analysis of covariance: ANCOVA)を行った。体力・運動能力と身体活動量との関倸は, 偏相関分析を用いた。これらの分析において調整因子は, 性，年齢，身長，体重としたささらに，PEの受講捛よ びSCへの参加の有無の比較には, ANCOVAを用いて, 目的変数を体力 - 運動能力の各変数, 共変量を性, 年齢,
身長，体重，PARが 2 以上 3 未満， 3 以上 4 未満招 よび 4 以上の所要時間, 説明変数を $\mathrm{PE}$ の受講およびSC への参加の有無として評価した，統計上の有意水準は全 て両側 $5 \%$ 未満とした。

\section{結果}

対象者の身体的特徽, 体力・運動能力および身体活動 量の結果を Table 1 に示した。身体的特徵には, 性差が 見られなかった。体力・運動能力については, 男子が, 女子に比較して, 立ち幅跳び, とび越しくぐりおよびZ 得点の積算值が有意に優れていた，身体活動量について は, 男子が, 女子と比較して, PARが 3 以上 4 未満抒 よび 4 以上の所要時間が有意に長く, また, PALも有意 に高かった。

対象者のうち，PEを受講していた者は149名，受講し ていなかった者は 42 名であった。受講頻度は, 週に 1 回 が129名，週に 2 回が20名であった。指導時間は，37.6土 10.9分/回であった。また，質問紙により得られたPEの 指導内容は, Table 2 に示した. SCへ参加していた者は 95名，参加していなかった者は96名であった，参加頻 度は, 週に 1 回が 63 名, 週に 2 回以上が 32 名であった。 所要時間は, $63.8 \pm 23.2$ 分/回であった．種目別にみると, 水泳 (42.9\%, 54名参加/126種目), 体操 (17.5\%, 22名参加 /126種目）抢よびサッカー（15.9\%, 20名参加/126種目） の順に参加者数が多く，その他，バレエ，空手など，多 岐に亘っていた。

対象者の体力 - 運動能力あるいは身体活動量と, $\mathrm{PE}$ の受講およびSCへの参加の有無との関係について, 性, 年齢, 身長および体重を調整したANCOVAにより検討 した (Table 3).PEを受講していた群は, 受講していな かった群と比較して, とび越しくぐりと $25 \mathrm{~m}$ 走が劣っ ており，また，PARが4 以上の所要時間も短かった。一 方で，SCへ参加していた群は参加していなかった群に 比較して, 握力, $25 \mathrm{~m}$ 走および $\mathrm{Z}$ 得点の積算值が有意に 優れていた． SCへ参加していた群と参加していなかっ た群で, 身体活動量には差がみられなかった、また, 体力・ 運動能力と身体活動量の各変数間の関連について偏相関 係数を用いて検討した（Table 4)。その結果，立ち幅跳 びおよびとび越しくぐりは, PARが 3 以上〜 4 未満の 所要時間と, $20 \mathrm{~m}$ シャトルラン, 立ち幅跳び, とび越 しくぐり，25 m走抢よびZ得点の積算值は, PARが 4 以上の所要時間との間に有意な関係が見られた。

さらに, 体力・運動能力を目的変数, $\mathrm{PE}$ の受講打よ びSEへの参加の有無掞よび身体活動量を説明変数とし たANCOVAを行った（Table 5)。その結果, 何れの体力・

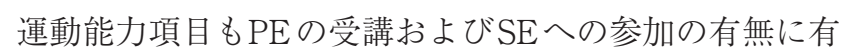
意な交互作用は認められなかった，身体活動量について は, 全ての体力・運動能力項目㧍よびZ得点の積算值 


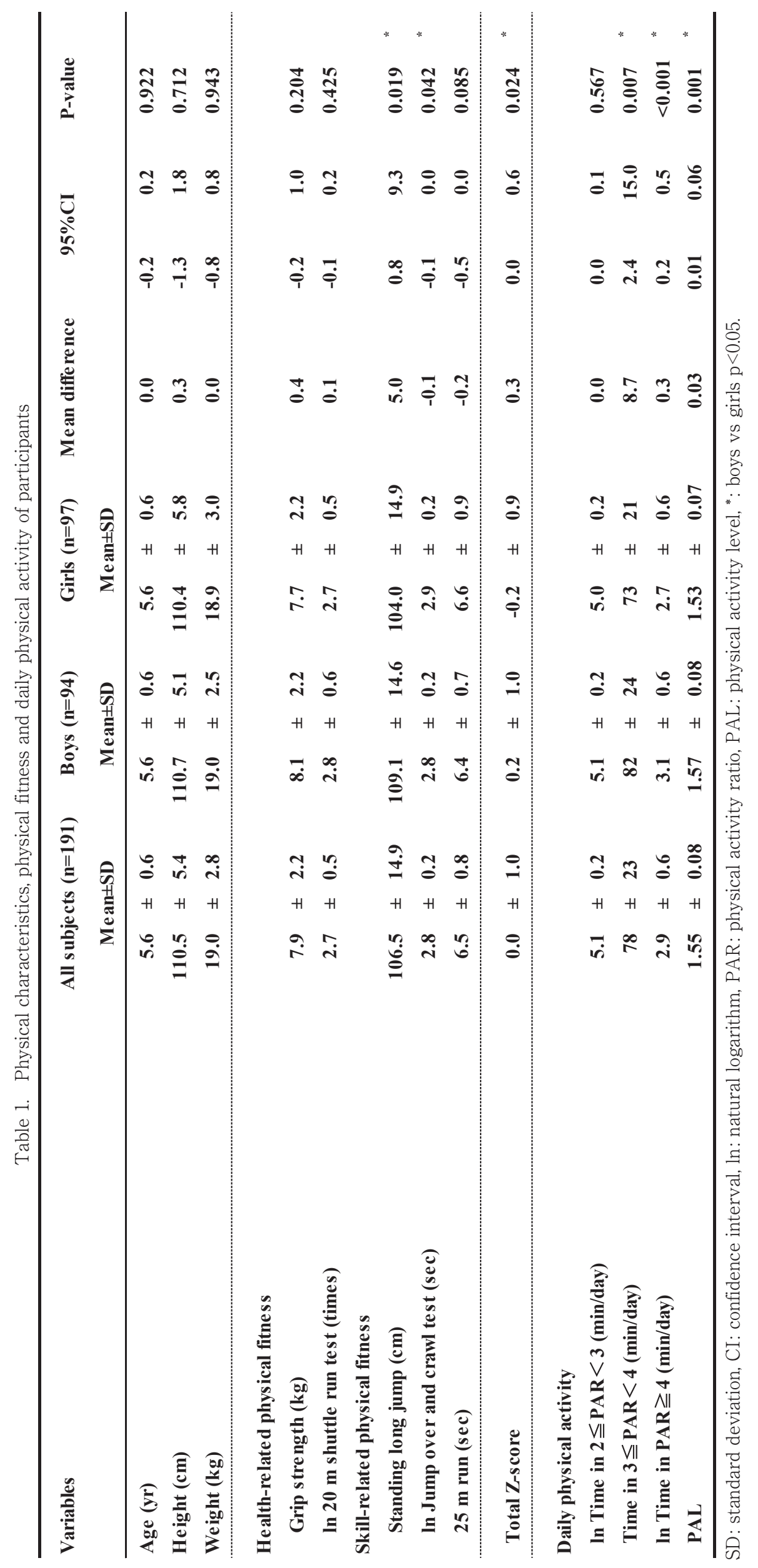


Table 2. Contents of physical education at the preschools

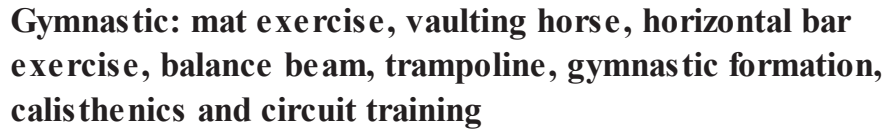

Ball game: ball playing, dodgeball, football

Run: individual race, relay, long-distance running

Jump rope

Hula-Hoop

Dance

Playing in water

Practice for a sports meeting

とPARが 4 以上の所要時間との間に有意な関係が見ら れ, PARが 4 以上の所要時間が長いと体力・運動能力 が優れていた。また，握力は，PARが 2 以上〜 3 未満 の所要時間と有意な関係が見られ，PARが 2 以上〜 3 未満の所要時間が短いと握力が優れていた。さらに握力 は，PEを受講していた群は，受講していなかった群に 比較して有意に優れていた $(\mathrm{p}<0.001)$ 。一方, $25 \mathrm{~m}$ 走は, PEを受講していた群は, 受講していなかった群に比較 して有意に劣っていた（ $\mathrm{p}=0.014 ）$ が，SCへ参加してい た群は参加していなかった群と比較して，有意に優れて いた（ $\mathrm{p}=0.030 ）$.

\section{考察}

本研究は, 日本における幼児期の運動・スポーツ指導 および運動・スポーツに限らない日常生活における身 体活動と体力・運動能力の関連を明らかにするために, 1 ）対象者が通う就学前の保育・教育施設内のPEの実 施状況，2）就学前の保育・教育施設外における SCへ の参加状況，3）幼児を対象に妥当性の検討を行った加 速度計 ${ }^{16,17)}$ を用いて評価した運動・スポーツを含む日常 生活全般における身体活動量, の3つと, 体力・運動能 力との関係をあわせて検討した点に特徵がある。その結 果, $\mathrm{PE}$ の受講や $\mathrm{SC}$ の参加の有無と体力 - 運動能力と の関係は限られており，PEの受講は握力と走力のみに, $\mathrm{SC}$ へ参加は走力のみに差がみられた。しかし, $\mathrm{PE} の$ 受講においては，受講群において握力が有意に高いもの の，走力は有意に劣っていた。また，SCへ参加していた 群は, 参加していなかった群と比較して走力が有意に優 れていた。一方で，日常生活におけるPARが4 以上の身 体活動の所要時間は，本研究で評価した全ての体力・運 動能力項目および総合力と, PARが 2 以上〜 3 未満の 身体活動の所要時間は握力と関連していることが明らか となった。

本研究の対象者の身体的特徵および体力・運動能力は,
最近の同年代の幼児の結果と同様であった ${ }^{21,23-25)}$ 。また, 本研究の対象者のSCにおける実施種目は, 主に水泳, 体操，サッカーであったが，その中でも，水泳 (42.9\%) が最も実施率の高い種目であった。この結果は，同年 代の習いごとを調査した先行研究6) と同様の結果であっ た。このように, SCでは特定の種目の実施に限られるの に対し，PEでの指導内容を見ると，特定の種目に限ら ず，様々な運動・スポーツ種目が実施されていた。その 中でも手を使って体を支持する運動，例えばマット運動 や鉄棒運動が含まれていたため，PEを受講した群は握 力との間に正の相関がみられたのかもしれない.さらに, 最も参加者が多かったSCの種目は水泳であったにも関 わらず，SCへの参加の有無と走力との間に関係が見ら れたのは，SCへの参加により特にその運動形態が単純 な走力に対して，筋力増加の影響が表れたのではないか と考えられる。あるいは, SCへ参加するための外出が, 影響を及ぼしていた可能性も考えられる。但し，SCへ参 加していた群のPARが 4 以上の所要時間は，参加して いなかった群と差がみられなかった。また, 本研究では, 種目毎の検討を行うまでの対象者数を得ることができな かったため，水泳を中心としたSCへの参加で走力と関 連がみられた原因については，今後の検討課題である。

体力・運動能力の総合評価については，PEおよびSC の両方において, 受講や参加の有無の差は見られなかっ た。この結果は，杉原ら ${ }^{8)}$ が運動指導をしていない幼稚 園と, 月に $1 \sim 6$ 回, あるいは 7 回以上の運動指導を行っ ている 3 群について， 6 種目の体力・運動能力の評定点 を比較し，運動指導の頻度が高くなるほど運動能力が有 意に劣っていたとする報告と矛盾する。この不一致の理 由は定かではないが，本研究では，杉原ら ${ }^{8)}$ が対象とし た幼稚園での研究と比較して，PEを受講していた幼児 のうち，86.6\%の幼児において受講頻度が週に 1 回（月 に4 回）と，少なかったことが影響しているのかもしれ ない.また, 本研究における身体活動量の結果において, 


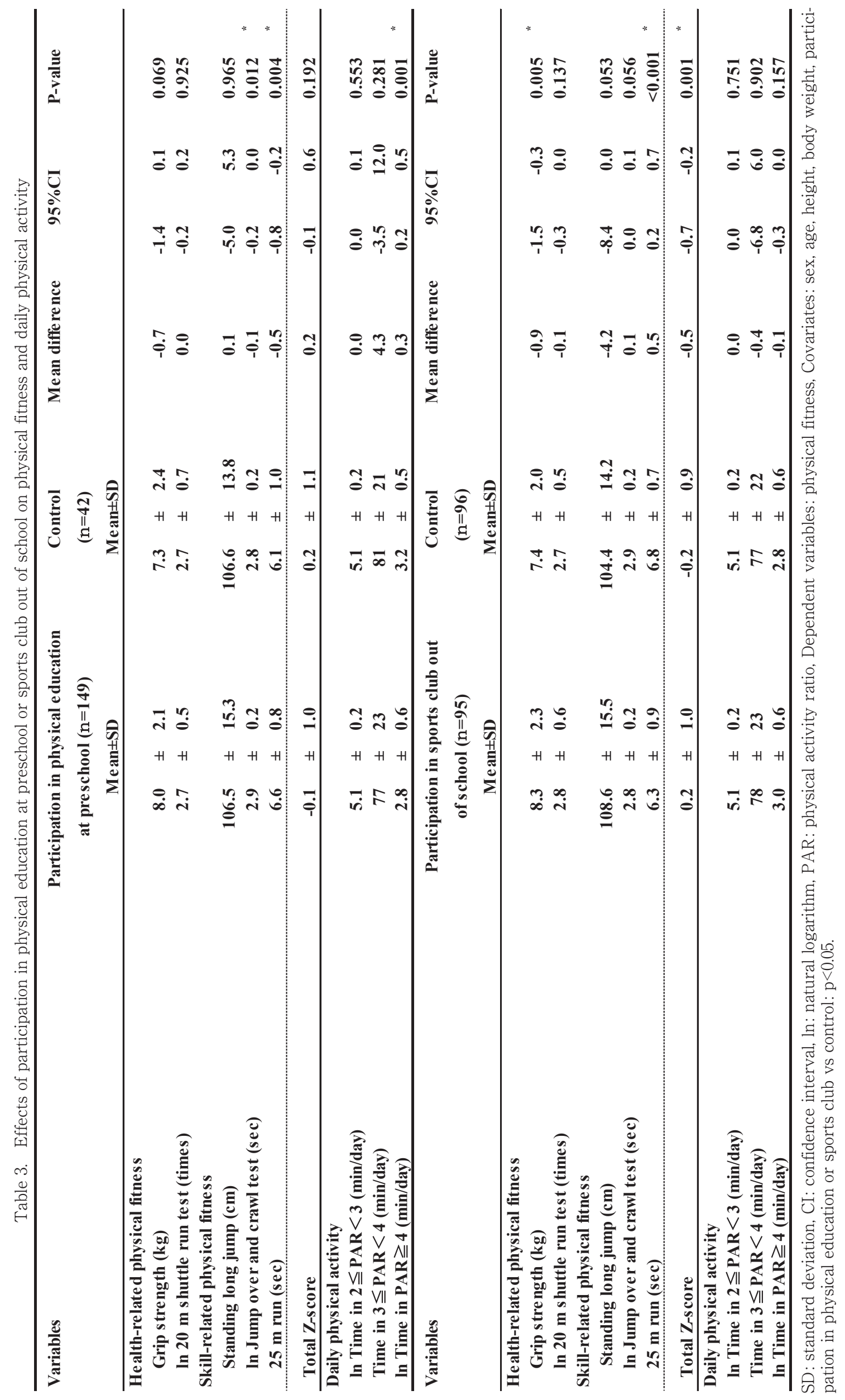



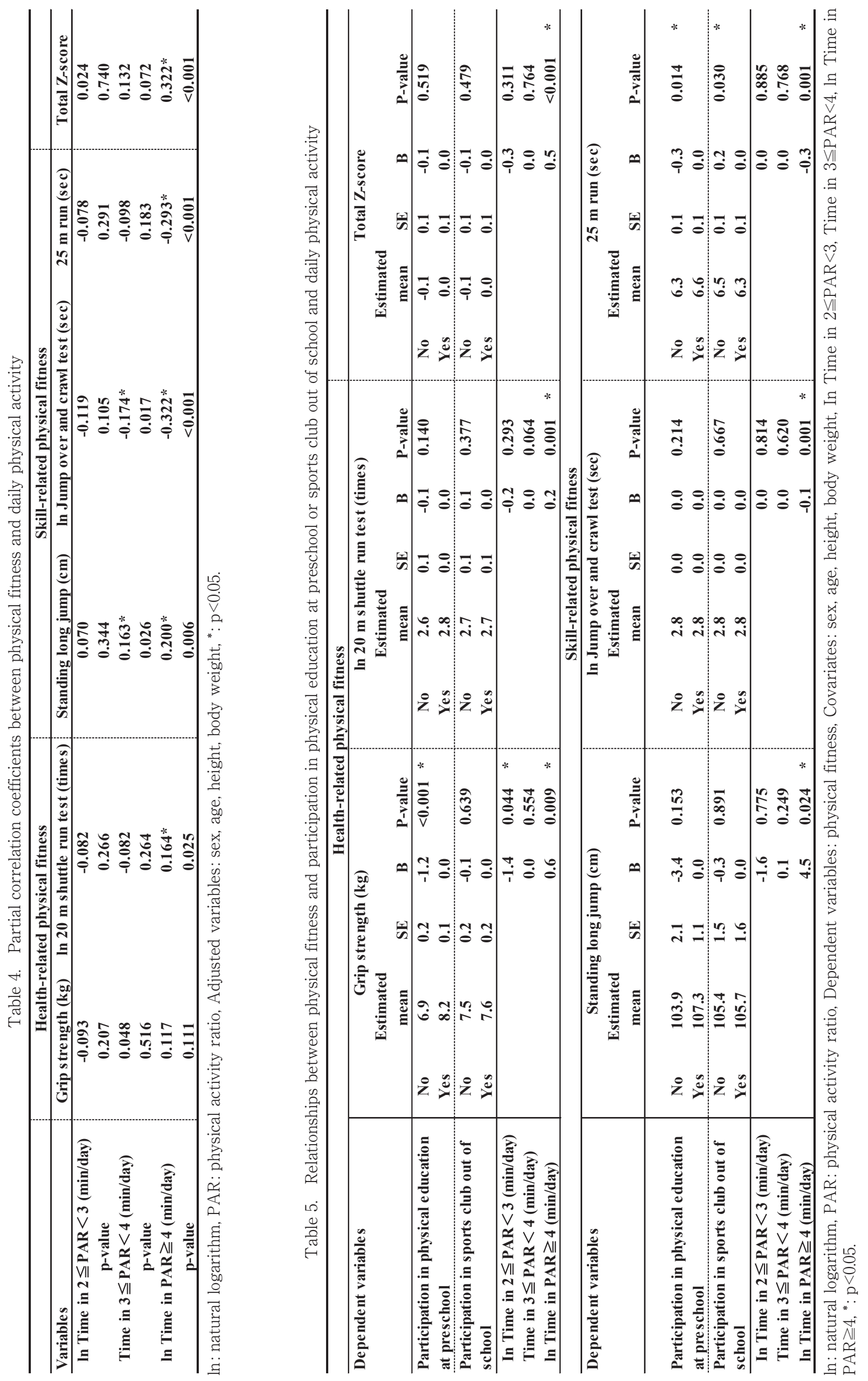
PEを受講していた群は, 受講していなかった群に比較 して, PARが 4 以上の所要時間が有意に短かった。この ことは，杉原ら ${ }^{8)}$ も指摘しているように，運動指導時の 待ち時間が長いために実際に身体を動かす時間が短いこ となどが走力に影響を及ぼしている，という仮説にあっ た結果である。

体力・運動能力と, 身体活動量, $\mathrm{PE}$ の受講およびSC への参加の有無との関係についてあわせて検討した結 果, 握力は, PEの受講とPARが 2 以上〜 3 未満および $\mathrm{PAR}$ が 4 以上の身体活動の所要時間が，走力は， $\mathrm{SC}$ 一 の参加の有無とPARが 4 以上の身体活動の所要時間の 両方が，また，その他の全ての体力・運動能力項目およ びZ得点の積算值は, 運動習慣よりも, PARが 4 以上の 身体活動の所要時間が重要であることが明らかとなっ た。このように, $\mathrm{PE} の$ 受講やSCへの参加に比較して, 日常の自由な遊びや生活の中でのPARが 4 以上の身体 活動の所要時間が, 幼児の体力・運動能力にとって重要 であることが明らかとなったＰARが 4 以上の身体活 動としては, 例えばボール遊び（大きな動きを伴う場合） や走行が該当する ${ }^{16,17)}$. 本研究結果から体力・運動能力 と身体活動量の因果関係を明らかにすることはできない が, この点に関連して，スイス人幼児の体力・運動能力 と日常の身体活動量について 9 か月間に亘り，縦断的に 検討した報告がなされている ${ }^{9)}$ 。それによると，中・高 強度の身体活動量の初期值は敏捷性や動的平衡性の変化 と, さらに高強度の身体活動量の初期值は有酸素性能力 の変化と有意な関係が見られたものの, 敏捷性, 動的平 衡性抢よび有酸素性能力の初期值は, 各強度の身体活動 量の変化との間に有意な関係が見られなかった，対象者 や方法が異なるため一概には言えないものの, 本研究に おいても，体力・運動能力に優れていた対象者において PARが 4 以上の身体活動を積極的に行っていたと考え るよりも，PARが 4 以上の身体活動の実施が体力・運 動能力を高めていたと解釈する方が適切かもしれない， その場合，遊びを中心とした生活を送る幼児では，PEあ るいはSCでの特定のスポーツ種目といった，組織化さ れた運動・スポーツの参加に関わらず，日々の生活を通 してPARが 4 以上の身体活動を行うことにより，全身 持久力, 瞬発力, 敏捷性㧍よび総合的な体力・運動能力 を高められる可能性が示唆された。本研究の対象者にお けるPARが 4 以上の時間が 1 日当たり 20 分程度だった のに対し, PEやSCは, 多くの場合, 週 1 回（約30６0分） であることを考えると, 当然の結果とも言える。一方で, $\mathrm{PE}$ の受講やSCへの参加の有無において握力や $25 \mathrm{~m}$ 走 に差がみられたことは，PARが4 以上の身体活動の所 要時間だけでは説明しきれず，運動指導・教室参加にも 何らかの意義があるものと考えられる。しかしながら， たとえPEの受講やSCへ参加する機会が無い場合でも，
幼児が自由に遊ぶ事ができる場の提供など，周囲の大人 が環境を整えることで，幼児は体力・運動能力を高めら れる可能性があるかもしれない，ただし，これらはあく まで横断的な結果に基づく推測であり, 縦断的な観察や 介入に基づく検討が必要である。

本研究の限界点として, 本研究の対象者募集は, 対象 者として保護者が同意した関東圈の幼稚園および保育所 に通っていた幼児を対象としたため, 結果の一般性につ いては，慎重に検討する必要がある，特に，PEの受講 やSCへの参加による効果については，大人数のランダ ムサンプリングに基づいているわけではないため，対象 者の偏りがある可能性は否定できない。また，SCにお いて最も多く対象者が参加していた運動・スポーツは, 水泳であったものの, 本研究で用いた加速度計では水泳 中の身体活動量を計測できなかった，さらに，本研究は 横断的研究であったため, 今後縦断的な検討が望まれる.

\section{結 語}

幼児の体力・運動能力に扔いて, 全ての体力 $\cdot$ 運動能 力項目とPARが 4 以上の日常の身体活動の所要時間に 有意な関係がみられた。さらに筋力は， $\mathrm{PE} の$ 受講，走力 は，SCへの参加とも有意な関係が見られた。また， $\mathrm{PE}$ の受講は走力に負の有意な関係が見られた。そのため, 幼児の体力・運動能力を高めるためには, 組織的な運動. スポーツだけでなく，幼児が自発的に取り組む遊びをは じめとする身体活動が重要な役割を果たしているかもし れないと考えられた。今後，運動・スポーツの実施によ り運動有能感が高まる可能性など心理的側面や，運動技 能との関係についても，検討すべき課題である。

\section{謝 辞}

本研究にご参加頂いた幼稚園および保育所の幼児や保護 者, 本研究の実施に際し多大なるご協力をいただいた各幼 稚園扮よび保育所の皆様, 独立行政法人国立健康・栄養研 究所の小暮宽子氏拉よびスタッフの皆様，掞よび首都大学 東京大学院准教授の稲山貴代博士に深謝致します。本研究 は, 財団法人 上月スポーツ・教育財団 第 7 回（2009年度） 「スポーツ研究助成事業」（研究代表者：田中千晶）打よ び住友生命健康財団 2010年度 スミセイ コミュニティス ポーツ推進助成プログラム（研究代表者：田中千晶）から 研究助成を受けて実施したものである。

\section{引用文献}

1) Sugihara T, Kondo M, Mori S, Yosida I. Chronological change in preschool children's motor ability development in Japan from the 1960s to the 2000s. Int J Sport Health Sci 4: 49-56, 2006.

2）文部科学省：平成23年度全国体力・運動能力, 運動習慣 等調查結果, 2012

3）文部科学省幼児期運動指針策定委員会：幼児期運動指 
針, 2012 .

4）文部科学省：学校基本調査-平成21年度, 2010 .

5）厚生労働省：保育所保育指針, 2008.

6）笹川スポーツ財団：子どものスポーツライフ・データ 2010-4～9歳のスポーツライフに関する調査報告書 - , 笹川スポーツ財団, 東京, 2010.

7）文部科学省：平成19年度全国体力 - 運動能力, 運動習慣 等調査結果, 2008.

8）杉原 隆, 吉田伊津美, 森 司朗, 筒井清次郎, 鈴木康弘, 中 本浩揮, 近藤充夫 : 幼児の運動能力と運動指導ならびに 性格との関係, 体育の科学, 60: 341-347, 2010.

9) Bürgi F, Meyer U, Granacher U, Schindler C, MarquesVidal P, Kriemler S, Puder JJ. Relationship of physical activity with motor skills, aerobic fitness and body fat in preschool children: a cross-sectional and longitudinal study (Ballabeina). Int J Obes (Lond) 35: 937-944, 2011.

10) Cliff DP, Okely AD, Smith LM, McKeen K. Relationships between fundamental movement skills and objectively measured physical activity in preschool children. Pediatr Exerc Sci 21: 436-449, 2009.

11) Fisher A, Reilly JJ, Kelly LA, Montgomery C, Williamson A, Paton JY, Grant S. Fundamental movement skills and habitual physical activity in young children. Med Sci Sports Exer 37: 684-688, 2005.

12) Tanaka C, Hikihara Y, Ohkawara K, Tanaka S. Locomotive and non-locomotive activity as determined by triaxial accelerometry and physical fitness in Japanese preschool children. Pediatr Exerc Sci 24: 420-434, 2012.

13) Tanaka C, Tanaka S. Objectively-measured physical activity and body weight in Japanese preschoolers. Ann Hum Biol 40: 541-546, 2013.

14) Williams HG, Pfeiffer KA, O'Neill JR, Dowda M, McIver KL, Brown WH, Pate RR. Motor skill performance and physical activity in preschool children. Obesity (Silver Spring) 16: 1421-1426, 2008.

15) Wilkin TJ, Mallam KM, Metcalf BS, Jeffery AN, Voss LD. Variation in physical activity lies with the child, not his environment: evidence for an 'activitystat' in young children (EarlyBird 16). Int J Obes (Lond) 30: 1050-1055, 2006.

16) Tanaka C, Tanaka S, Kawahara J, Midorikawa T. Triaxial Accelerometry for Assessment of Physical Activity in Young Children. Obesity 15: 1233-1241, 2007.

17) Kawahara J, Tanaka S, Tanaka C, Hikihara Y, Aoki Y, Yonemoto J. Estimation of respiratory ventilation rate of preschool children in daily life by using an accelerometer. J Air \& Waste Manage Assoc 61: 46-54, 2011.

18) Institute of Medicine of the National Academies, 2005.

19) Puyau MR, Adolph AL, Vohra FA, Butte NF. Validation and calibration of physical activity monitors in children. Obes Res 10: 150-157, 2002.

20) Yamamura C, Tanaka S, Futami J, Oka J, IshikawaTakata K, Kashiwazaki H. Activity diary method for predicting energy expenditure as evaluated by a whole-body indirect human calorimeter. J Nutr Sci Vitaminol 49: 262-269, 2003.

21）首都大学東京体力標準值研究会：新 - 日本人の体力標 準值 II, 不昧堂, 東京, 2007.

22）栗本閲夫, 浅見高明, 渋川㑆二, 松浦義行, 勝部篤美 : 体 育科学センター調整力フィールドテストの最終形式一 調整力テスト検討委員会報告一, 体育科学, 9: 207-212, 1981.

23）文部科学省, 平成23年度学校保健統計調査, 2011.

24）村瀬智彦. 幼児の体力 - 運動能力の科学 - その測定評価 の理論と実際. 出村慎一 (監修), ナップ, 2005.

25）樋口 満, 佐竹 隆. からだの発達と加齢の科学, 高石昌弘 (監修), 大修館書店, 2012 . 